\title{
BEARING CAPACITY AND COMPRESSIBILITY ON IMPROVED LOESS BY COMPACTION AND CEMENT ADMIXTURE
}

\author{
* Dolrerdee Hormdee ${ }^{1}$, and Piyoros Jirawattana ${ }^{1}$ \\ ${ }^{1}$ Faculty of Engineering, Khon Kaen University, Thailand \\ *Dolrerdee Hormdee, Received: 30 March 2020, Revised: 21 April 2020, Accepted: 27 April 2020
}

\begin{abstract}
Geotechnical engineering always deals with the field or compacted condition using shear strength or deformation behavior. Khon Kaen loess soil can be classified as a moderate to moderately severe in collapse index. With long term infiltration, its cohesion is almost completely gone. Therefore, this research is aimed to study the behaviors of the bearing capacity and settlement of the compacted Khon Kaen loess soil with and without cement. The testing results from the laboratory and from the field can be shown that the soil and soil-cement stabilization are improved by $95 \%$ for modified compaction. This is due to the effects of initial density, initial water content, \%cement added, curing time duration and the size of the plate on the bearing capacity and deformation behavior. The results also show that the increasing in water content has the greatest influence to reduce in the bearing capacity but increase in compressibility of the specimens. However, for testing with the same energy of compaction but lower water content, less settlement at any pressures in the unsoaked condition with the more collapse settlement can be found. On the other hand, the 95\% modified compaction improvement, the collapse potential/ collapse index are almost negligible. Finally, with more cement added, less settlement with the more bearing capacity can be achieved.
\end{abstract}

Keywords: Unconfined compressive strength, Collapsibility, Soil-cement stabilization, Plate load test,

\section{INTRODUCTION}

Design and construction in geotechnical engineering, i.e. considering in slope area, foundation or excavation and compaction on ground, always deals with the unsaturated soil condition using the shear strength and deformation behavior.

Unfortunately, the strength is sharply reduced and the large settlement is occurred when water content increased. Especially collapsible soil i.e. Khon Kaen loess, in situ condition, the dry density is relatively low which is approximately $1.4-1.6 \mathrm{t} / \mathrm{m}^{3}$ but the shear strength is quite high [1]. As a result, when the moisture content increased, its major bearing capacity is reduced and large settlement is occurred. This is the major reason of buildings damage in Khon Kaen loess particularly damaging from differential settlement under soaking.

As in situ condition, Khon Kaen loess can be classified as moderate to moderately severe in collapsible index [2]. Therefore, many researchers [38] have been studying its behavior and trying to eliminate those problems by compaction and stabilizing soil with cement. Similarly, this research studies the behaviors of bearing capacity and settlement on improved Khon Kaen loess soil in laboratory and in the field testing. In addition, the effects of initial density, initial moisture content, \%cement added, curing time and the size of plate on bearing capacity and deformation behavior are presented.

\section{METHODOLOGY}

A disturbed red loess sample was collected at a depth of 1.5-2.0m below ground surface in Khon Kaen University, Thailand. Some of its index and engineering properties are shown in Table 1.

Table 1 Properties of soil

\begin{tabular}{lc}
\hline \multicolumn{1}{c}{ Property } & Khon Kaen loess soil \\
\hline Specific gravity $\left(\mathrm{G}_{\mathrm{s}}\right)$ & 2.59 \\
\%Passing \#4 & 100 \\
\%Passing \#200 & 35.5 \\
Liquid limit (LL) & $19.0 \%$ \\
Plastic limit (PL) & $12.5 \%$ \\
USCS & $\mathrm{SC}$ \\
OMC (Mod. Proctor) & $8.27 \%$ \\
$\rho_{\mathrm{d} \text { max }}$ (Mod. Proctor) & $2.11 \mathrm{t} / \mathrm{m}^{3}$ \\
Natural water content & $7.71 \%$ \\
$\rho_{\text {d,field }}$ & $1.44 \mathrm{t} / \mathrm{m}^{3}$ \\
\hline
\end{tabular}

To study bearing capacity and compressibility behaviors, a double oedometer test and an unconfined compression test are performed in laboratory. While in the field, a standard penetration test (SPT) and a plate load test are utilized.

\section{DOUBLE OEDOMETER TEST}

For the double oedometer test, unsoaked as re- 
compacted condition and soaked with water over the specimens are usually used to identify the collapse potential and collapse index. The collapse potential $\left(C_{p}\right)$ for any vertical pressure [9-10] is defined as

$$
C_{p}=\left(\frac{\Delta e}{1+e_{o}} \times 100\right)=\frac{\Delta H}{H_{o}} \times 100
$$

where

$\Delta \mathrm{e}$ is the differential void ratio due to the collapse,

$\mathrm{e}_{\mathrm{o}}$ is the initial void ratio,

$\Delta \mathrm{H}$ is the vertical settlement of the soil sample, and $\mathrm{H}_{0}$ is an initial thickness of the soil sample.

With the definition of the [11], the collapse index $\left(\mathrm{I}_{\mathrm{e}}\right)$ which based on different vertical strain between the soaked and unsoaked condition at a vertical pressure of $200 \mathrm{kPa}$ can then be defined. However, for differential vertical strain under a given pressure, the potential of soil collapse $\left(\mathrm{I}_{\mathrm{c}}\right)$ can be indicated.

In addition, the collapsibility which referred on the collapse potential is shown in Table 2 . This collapse index is used to classify the degree of collapse according to Table 3 .

Table 2 The potential collapsibility of soil from collapse potential [9-10]

\begin{tabular}{cl}
\hline $\mathrm{C}_{\mathrm{p}}(\%)$ & \multicolumn{1}{c}{ Collapsibility } \\
\hline $0-1$ & No collapse problem \\
$1-5$ & Moderately collapse problem \\
$5-10$ & Trouble (weak settlement) \\
$10-20$ & Severe trouble (Medium settlement \\
$>20$ & Very severe problem (marked settlement) \\
\hline
\end{tabular}

Table 3 Classification of Collapse Index, Ie [11]

\begin{tabular}{ll}
\hline \multicolumn{1}{c}{$\mathrm{I}_{\mathrm{e}}(\%)$} & Degree of Collapse \\
\hline 0 & None \\
0.1 to 2.0 & Slight \\
2.1 to 6.0 & Moderate \\
6.1 to 10.0 & Moderately severe \\
$>10$ & Severe \\
\hline
\end{tabular}

As using disturbed samples, they were prepared in 'identical' fashion by controlling initial water content, initial dry density and content of cement as shown in Table 4 . This can be done by using hydraulic jack to slowly press the samples into the oedometer ring of $61.2 \mathrm{~mm}$ in diameter and $25.4 \mathrm{~mm}$ in height, as shown in Fig.1. For curing the soil-cement specimens, the zip lock plastic bag is also required.

In Fig. 2 are the results of the re-compacted specimens from the field condition. It is illustrated that the deformation with pressure of an unsoaked sample is less than that of a soaked sample due to collapsibility. In addition, the collapse potential is
Table 4 Scope of Double Oedometer Test

\begin{tabular}{|c|c|c|c|}
\hline $\begin{array}{l}\text { Type of } \\
\text { material }\end{array}$ & $\begin{array}{l}\text { Re-compacted } \\
\text { condition }\end{array}$ & $\begin{array}{l}\text { Testing } \\
\text { condition }\end{array}$ & $\begin{array}{c}\text { Curing time } \\
\text { (days) }\end{array}$ \\
\hline Soil & $\begin{array}{l}\text {-As field condition } \\
\text { •95\% @wet side } \\
\text { •95\% @dry side }\end{array}$ & $\begin{array}{l}\text { Unsoaked } \\
\text { and soaked }\end{array}$ & - \\
\hline $\begin{array}{l}\text { Soil-5\% } \\
\text { cement }\end{array}$ & $\begin{array}{l}95 \% @ \text { wet side } \\
\text { of OMC }\end{array}$ & $\begin{array}{l}\text { Unsoaked } \\
\text { and soaked }\end{array}$ & \\
\hline
\end{tabular}
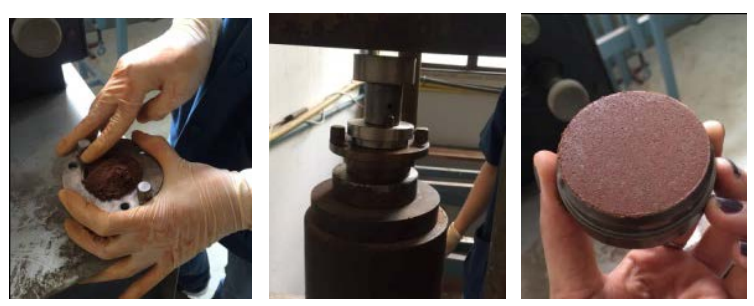

Fig.1 Preparation of Oedometer specimen

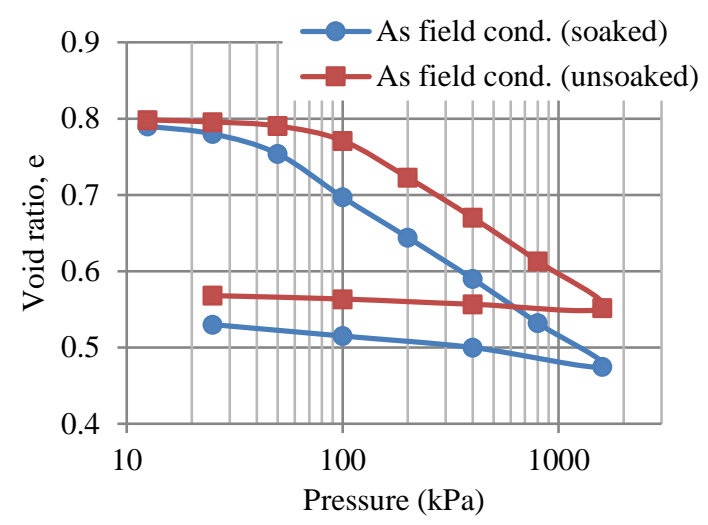

Fig.2 Double Oedometer testing results on as field condition of soil

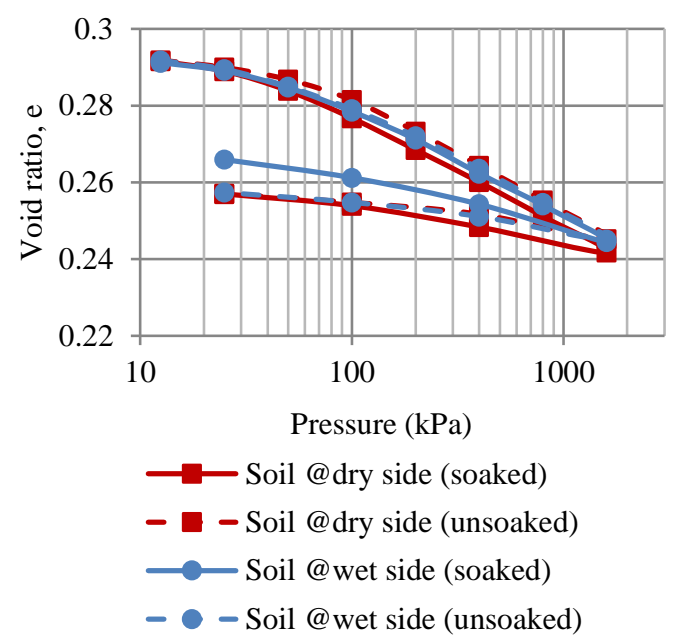

Fig.3 Double Oedometer testing results on 95\% modified compacted soil

about 1-4.5 (as shown in Fig.6) which classified to moderately collapse problem. However, when the soil and soil-cement specimens are improved by $95 \%$ 
modified compaction with both dry and wet side of optimum moisture content, the e-log p curve presents the same trend for all condition including soaked and unsoaked case as shown in Figs.3 and 4. When the deformation is compared between that of the field condition and that of $95 \%$ compaction (as shown in Fig.5), it shows much less compressibility on compacted soil with less collapsibility (as shown in Fig.6 and Table 5) for collapse potential and collapse index, respectively. This means that the collapsibility on this soil can be eliminated by high compaction.

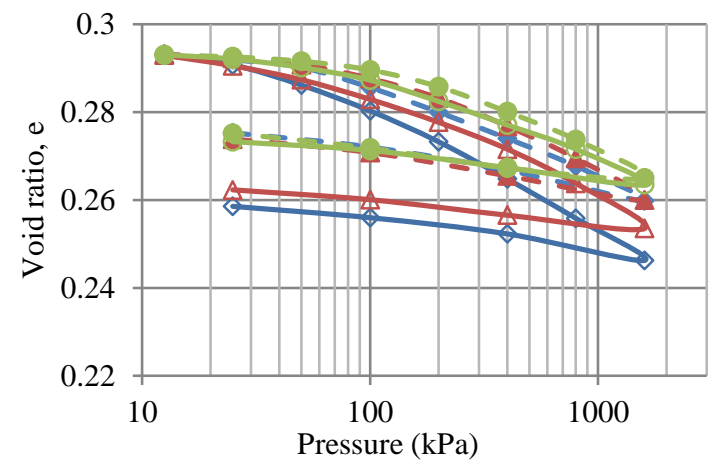

$$
\begin{array}{ll}
\longrightarrow \text { SC } 1 \text { day (soaked) } & -\leftarrow-\text { SC } 1 \text { day (unsoaked) } \\
\square \text { SC } 7 \text { days (soaked) } & -\neq- \text { SC } 7 \text { days (unsoaked) } \\
\square \text { SC } 28 \text { days (soaked) } & -\bullet-\text { SC } 28 \text { days (unsoaked) }
\end{array}
$$

Fig.4 Double Oedometer testing results on 95\% modified compacted soil-cement

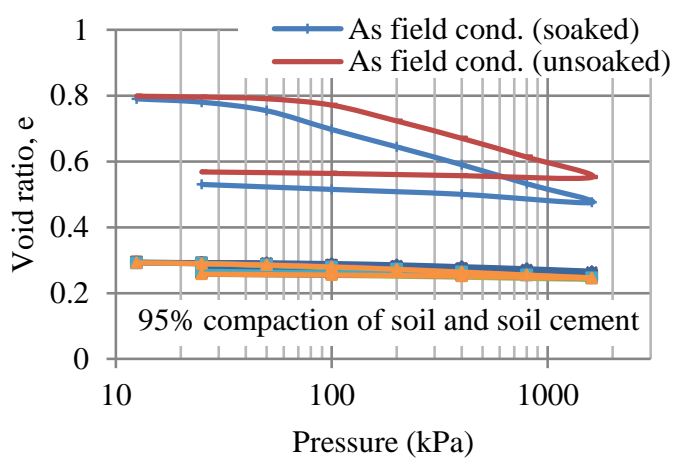

Fig.5 Comparison of Double Oedometer testing results on no improved soil, improved soil and improved soil-cement

\section{UNCONFINED COMPRESSION TEST}

The admixture and testing program are shown in Table 6 . The amount of mixture was pressed statically into a $50 \mathrm{~mm}$ in diameter and $10 \mathrm{~mm}$ in height mold as shown in Fig.7. A zip lock plastic bag is still used to cure the soil-cement specimens. The speed of testing was $1 \mathrm{~mm} / \mathrm{min}$ and the testing results are shown in Table 7.

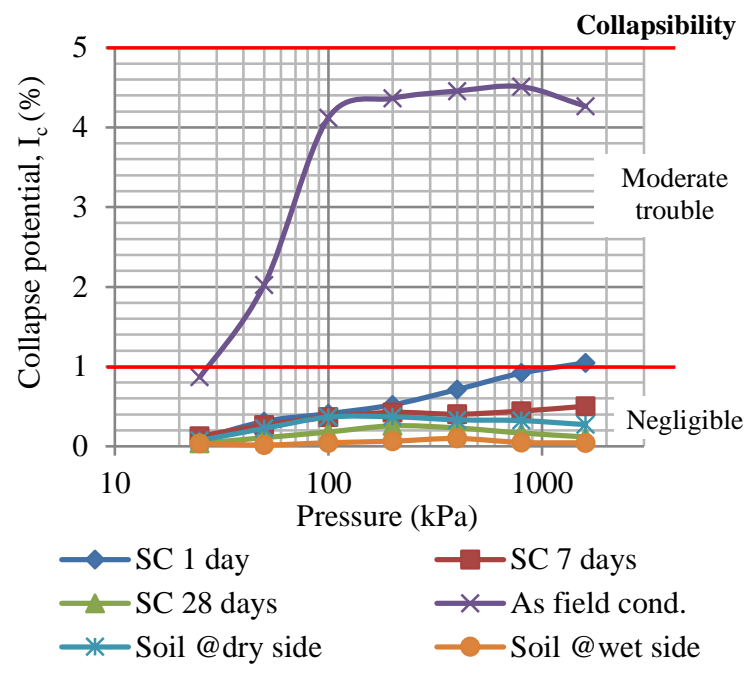

Fig.6 Relationship between Collapse Potential, $I_{c}$, and pressure

Table 5 Collapse Index $\left(I_{e}\right)$ and degree of collapse

\begin{tabular}{|c|c|c|c|}
\hline Material & $\begin{array}{l}\text { Re-compacted } \\
\text { condition }\end{array}$ & \%Cement & $\begin{array}{c}\text { Curing time } \\
\text { (days) }\end{array}$ \\
\hline Soil & $\begin{array}{l}\text { •As field condition } \\
\text { •100\%mod.@OMC } \\
\text { •95\%mod.@wet side } \\
\text { •95\%mod.@dry side }\end{array}$ & - & - \\
\hline $\begin{array}{l}\text { Soil- } \\
\text { cement }\end{array}$ & $\begin{array}{l}\text { 95\%mod.@ wet side } \\
\text { of OMC }\end{array}$ & $3,5,7 \%$ & $1,7,28$ \\
\hline
\end{tabular}

\begin{tabular}{ccccc}
\hline S:C & $\begin{array}{c}\text { Re-compaction } \\
\text { Condition }\end{array}$ & $\begin{array}{c}\text { Curing } \\
\text { Time } \\
\text { (day) }\end{array}$ & $\begin{array}{c}\text { Collapse } \\
\text { Index, } I_{e} \\
(\%)\end{array}$ & $\begin{array}{c}\text { Degree } \\
\text { of } \\
\text { Collapse }\end{array}$ \\
\hline As field & - & 4.36 & Moderate \\
100:0 & $\begin{array}{c}\text { recompaction } \\
95 \% \text { @ dry side }\end{array}$ & - & 0.37 & Slight \\
& $95 \%$ @ wet side & - & 0.06 & Slight \\
\hline 95\% @ wet side & 1 & 0.52 & Slight \\
95:5 95\% @ wet side & 7 & 0.43 & Slight \\
& $95 \%$ wet side & 28 & 0.26 & Slight \\
\hline
\end{tabular}

Table 6 Scope of Unconfined Compression Test
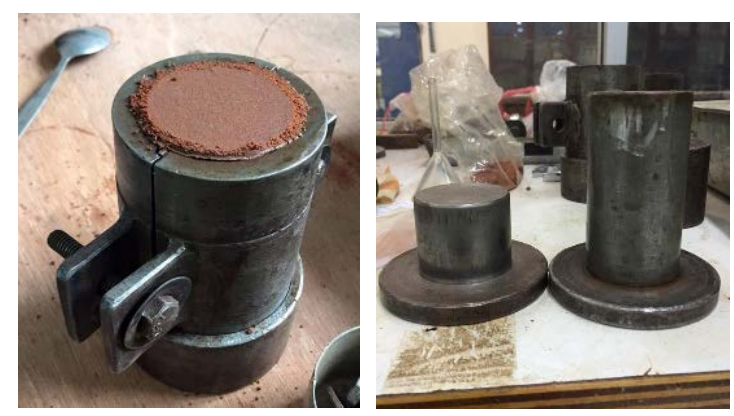

Fig.7 Mold and two-step tamper 
Table 7 The results of Unconfined Compression Test

\begin{tabular}{ccccccc}
\hline $\begin{array}{c}\text { Mat- } \\
\text { erial }\end{array}$ & \%Comp.. & $\begin{array}{c}\text { Avg. } \\
\% m_{\text {in }}\end{array}$ & $\begin{array}{c}\text { \% } \\
\text { Cement }\end{array}$ & $\begin{array}{c}\text { Curing } \\
\text { time } \\
\text { (day) }\end{array}$ & $\begin{array}{c}\text { Avg qu } \\
\text { (UCS). }\end{array}$ & $\begin{array}{c}\text { Avg. } \\
\% m_{f}\end{array}$ \\
\hline S & $\begin{array}{c}\text { As Field } \\
\text { Cond. }\end{array}$ & 7.8 & - & - & 1.81 & 7.6 \\
\hline S & 95 & 6.5 & - & - & 21.19 & 6.3 \\
\hline S & 100 & 8.7 & - & - & 8.63 & 8.6 \\
\hline S & 95 & 10.9 & - & - & 4.99 & 10.9 \\
\hline S-C & 95 & 11.5 & 3 & 1 & 45.94 & 11.0 \\
\hline S-C & 95 & 11.7 & 3 & 7 & 79.46 & 11.2 \\
\hline S-C & 95 & 11.7 & 3 & 28 & 115.52 & 10.9 \\
\hline S-C & 95 & 10.7 & 5 & 1 & 61.45 & 10.1 \\
\hline S-C & 95 & 10.8 & 5 & 7 & 146.7 & 9.8 \\
\hline S-C & 95 & 10.5 & 5 & 28 & 172.60 & 9.8 \\
\hline S-C & 95 & 11.0 & 7 & 1 & 71.47 & 10.7 \\
\hline S-C & 95 & 10.9 & 7 & 7 & 200.69 & 10.3 \\
\hline S-C & 95 & 11.0 & 7 & 28 & 300.27 & 8.4 \\
\hline
\end{tabular}

For the compacted soil with the same energy, the unconfined compression strength (UCS) in Fig.8 illustrates a good relationship in term of power function but unlike to the result of re-compacted for the field condition with different energy compaction. Nevertheless, as the wet side of OMC produces less of UCS, soil cement mixed is considered at only $95 \%$ modified compaction with wet side of OMC. Then, the effects of \% cement content and curing time on UCS can be shown in Figs.9 and 10, respectively. It can be seen that by increasing \%cement content results in higher USC and cost. In addition, according to the Standard no. DH-S. 204-2556 from Department of Highway (DOH) in Thailand, the UCS obtained from soil cement stabilization for base or subbase should not be less than 250 psi or $175.8 \mathrm{t} / \mathrm{m}^{2}$ after 2 hours soaked at 7 days curing. In this case, Khon Kaen loess soil should be mixed with more than $6 \%$ cement to meet this requirement. Figure 10 illustrates the effect of curing time on the strengths of soil cement. It can be seen that the strength increasing rate for the first week is higher than that of the rest of the curing time.

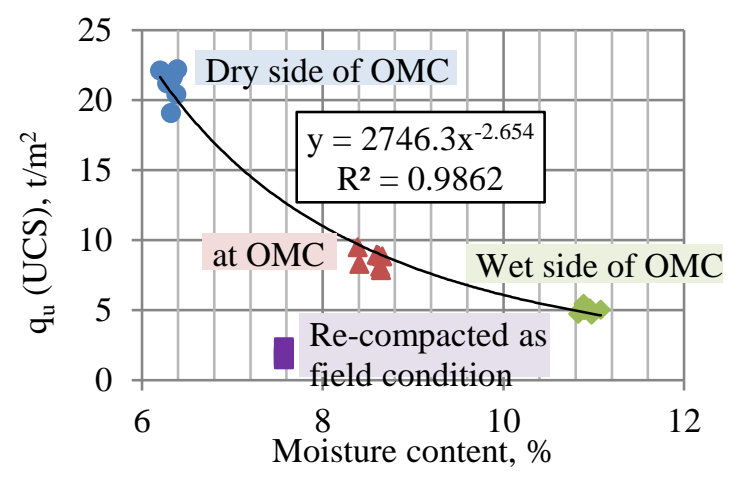

Fig.8 The relationship of UCS on the different conditions of compacted soil.

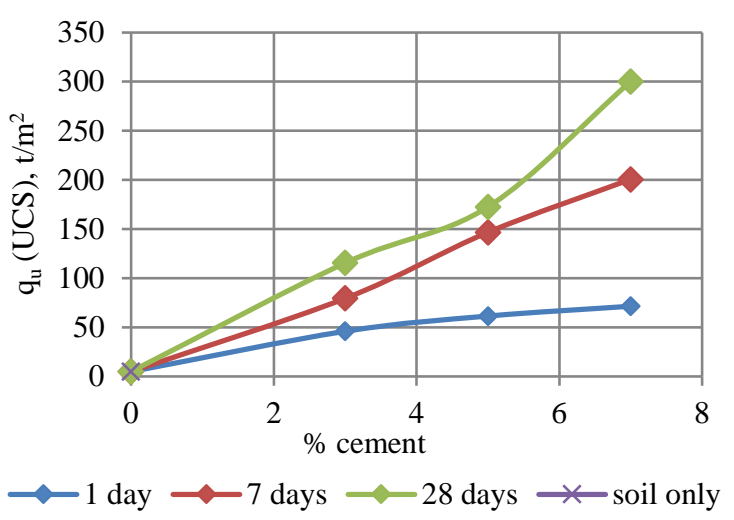

Fig.9 Effect of \%cement on UCS of 95\% modified compacted soil on wet side of OMC.

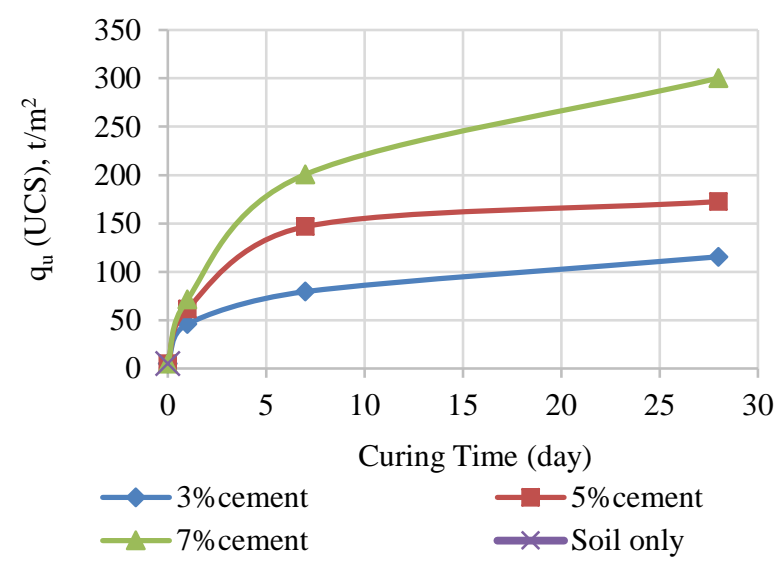

Fig.10 Effect of curing time on UCS of 95\% modified compacted soil on wet side of OMC.

\section{FIELD TEST}

The first state is for natural in situ condition which is the test for SPT and field density. The result of the boring test is shown in Table 8. The second state is for 95\% modified compaction in wet side of OMC with and without $5 \%$ cement stabilization (as the minimum requirement of DOH). Each test pits is W5 x L15 x $\mathrm{H} 2 \mathrm{~m}$. as shown in Figs.11 and 12. The last state is the plate load test which is still the soil cement stabilized ground. A $0.1 \times 0.1 \mathrm{~m}$ plate with $25 \mathrm{~mm}$ thick is mainly used in this research. Piles are also applied as gravity load. Four dial gauges are set at the corner of the plate via the reference beam to record the settlement values as shown in Fig.13. The test program is provided in Table 9. For each loading steps, the settlement was measured at 1, 2, 4, 8, 15, and 30 minutes and after that for every one-hour interval until $0.2 \mathrm{~mm} /$ hour rate of settlement can be achieved [12]. Noted that the load was increasing until the total settlement of $25 \mathrm{~mm}$ had reached.

The test results on compacted soil and soil cement at $95 \%$ modified proctor with wet side of optimum moisture content show that all failure mode is the local shear as shown in Figs. 14 to 16 . The ultimate bearing capacity is defined as the pressure 
corresponding to that break point on the graph $\left(\mathrm{q}_{\mathrm{u}}(\mathrm{b})\right)$ [13] or the corresponding pressure at $25 \mathrm{~mm}$ of settlement $\left(\mathrm{q}_{\mathrm{u}(25)}\right)$ [14].The summary of the plate load test result and SPT are provided in Table 10.

Table 8 The result of boring test in natural ground condition

\begin{tabular}{|c|c|c|c|c|c|}
\hline $\begin{array}{l}\text { Depth } \\
\text { (m.) }\end{array}$ & Sample Type & $\mathrm{N}$ & $\% m$ & $\begin{array}{c}\gamma_{d} \\
\left(t / m^{3}\right)\end{array}$ & $\begin{array}{c}\text { Pocket } \\
\text { Penetro- } \\
\text { meter test } \\
\text { (ksc) }\end{array}$ \\
\hline $0.0-0.74$ & \multirow{2}{*}{$\begin{array}{l}\text { Medium dense } \\
\text { silty Sand(SM) }\end{array}$} & 11 & 7.25 & 1.51 & 3.1 \\
\hline $0.74-1.2$ & & 14 & 7.00 & 1.55 & 2.9 \\
\hline $1.2-1.5$ & \multirow{7}{*}{$\begin{array}{c}\text { Medium dense } \\
\text { clayey } \\
\text { Sand(SC) }\end{array}$} & 16 & 6.71 & 1.65 & 3.8 \\
\hline $1.5-2.0$ & & 15 & 6.25 & 1.61 & 3.5 \\
\hline $2.0-2.5$ & & 16 & 6.28 & 1.64 & 3.5 \\
\hline $2.5-3.2$ & & 17 & 6.15 & 1.64 & 3.5 \\
\hline $3.2-4.0$ & & 22 & 7.02 & 1.77 & 4.2 \\
\hline $4.0-4.5$ & & 21 & 7.22 & 1.75 & 4.2 \\
\hline $4.5-5.0$ & & 24 & 6.33 & 1.68 & 4.0 \\
\hline $5.0-5.5$ & $\begin{array}{l}\text { Dense clayey } \\
\text { Sand(SC) }\end{array}$ & 42 & 6.72 & 1.59 & $>4.5$ \\
\hline
\end{tabular}

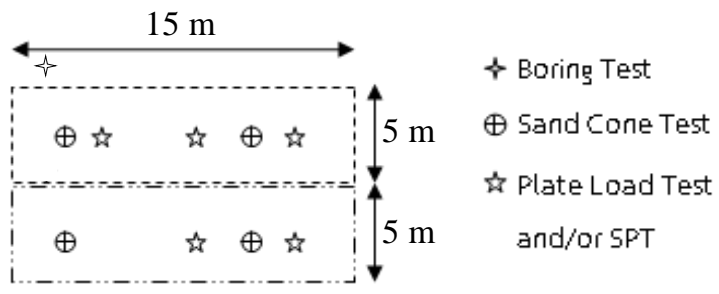

Compacted soil

i..-. Compacted soil-cement

Fig.11 Layout of field test
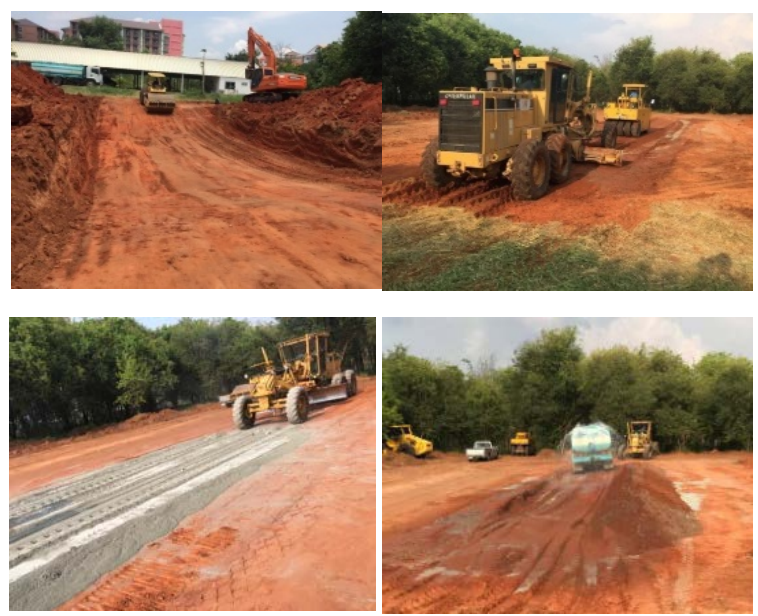

Fig.12 Compacted ground with and without cement stabilization
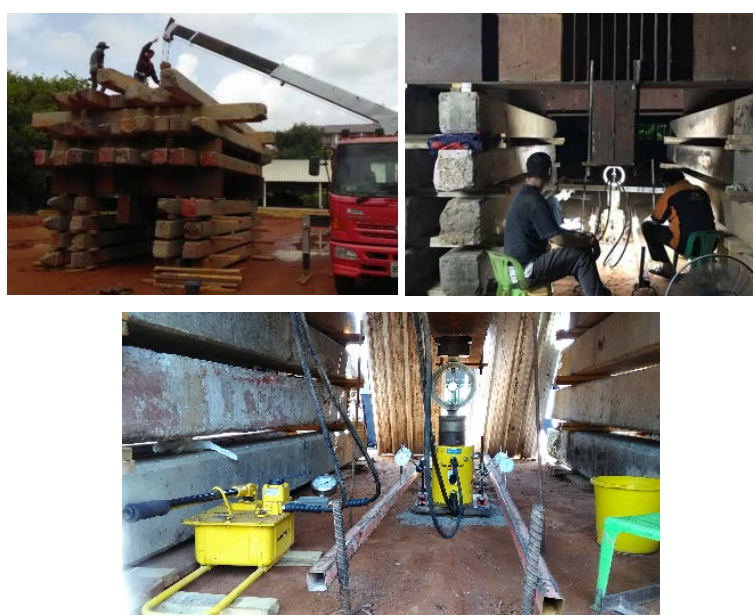

Fig.13 Plate load test installation

Table 9 Scope of plate load test

\begin{tabular}{cccc}
\hline \multirow{2}{*}{ Material } & $\begin{array}{c}\text { Compacted } \\
\text { condition }\end{array}$ & $\begin{array}{c}\text { Plate size } \\
(\mathrm{m})\end{array}$ & $\begin{array}{c}\text { Curing } \\
\text { time (days) }\end{array}$ \\
\cline { 1 - 3 } Soil & $95 \%$ & $0.1 \times 0.1$, & - \\
\cline { 1 - 1 } Soil-Cement & @wet side & $0.3 \times 0.3$ & - \\
\cline { 3 - 4 } & of OMC & $0.1 \times 0.1$ & 7 \\
\hline
\end{tabular}

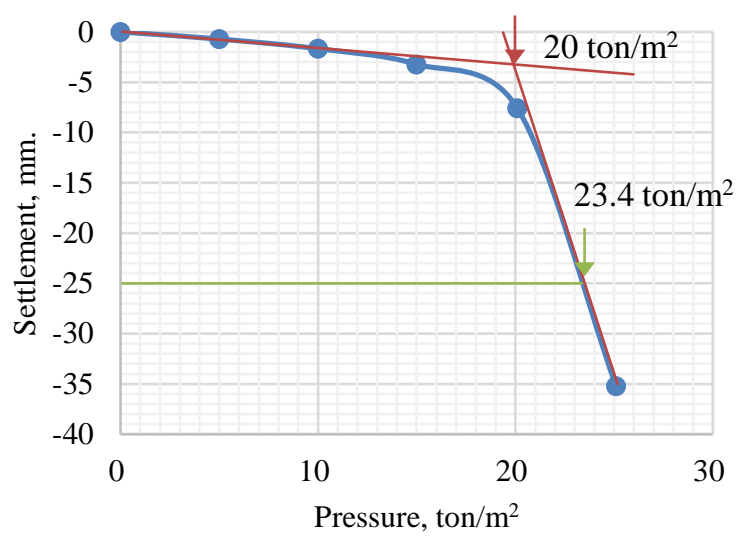

Fig.14 Pressure-settlement curve on compacted ground with $0.1 \times 0.1 \mathrm{~m}$ of plate

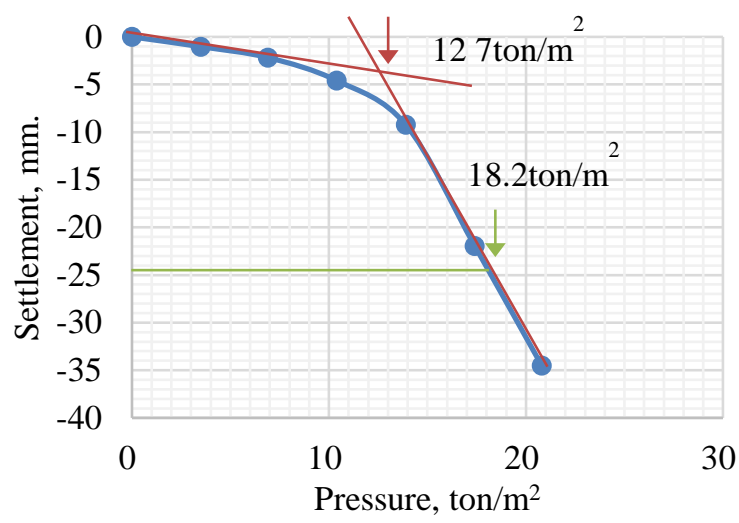

Fig.15 Pressure-settlement curve on compacted ground with $0.3 \times 0.3 \mathrm{~m}$ of plate 


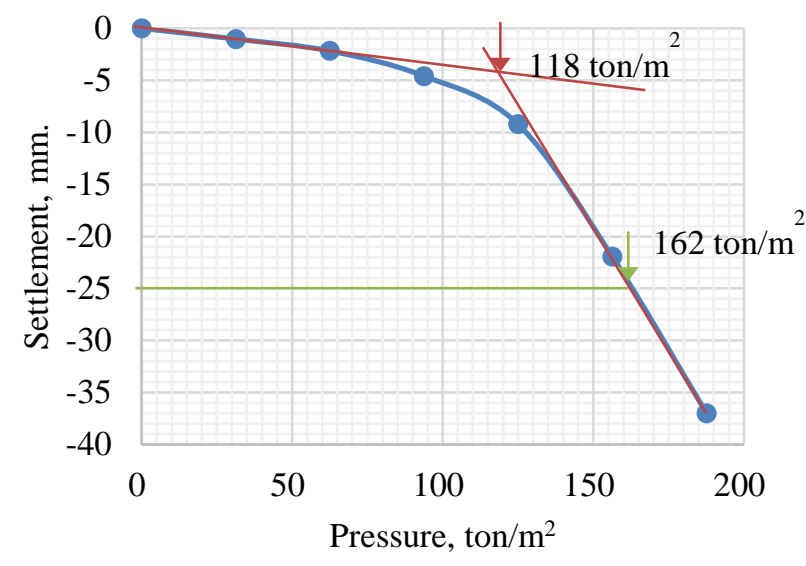

Fig.16 Pressure-settlement curve on compacted soilcement with $0.1 \times 0.1 \mathrm{~m}$ of plate

Table 10 The results of plate load test and SPT

\begin{tabular}{|c|c|c|c|}
\hline \multirow{2}{*}{ Properties } & \multicolumn{2}{|c|}{ Soil } & \multirow{2}{*}{$\begin{array}{c}\text { Soil-cemen } \\
\text { @7days }\end{array}$} \\
\hline & $0.1 \times 0.1 \mathrm{~m}$ & $0.3 \times 0.3 \mathrm{~m}$ & \\
\hline$\% \mathrm{~m}$ & 8.11 & 10.01 & 7.51 \\
\hline $\begin{array}{l}\text { Dry Density, } \\
\mathrm{t} / \mathrm{m}^{3}\end{array}$ & 2.027 & 1.98 & 2.00 \\
\hline \% Compaction & 96.1 & 93.8 & 94.9 \\
\hline $\mathrm{q}_{\mathrm{u}(25)}\left(\mathrm{t} / \mathrm{m}^{2}\right)$ & 23.4 & 18.2 & 162 \\
\hline $\mathrm{qu}(\mathrm{b})\left(\mathrm{t} / \mathrm{m}^{2}\right)$ & 20 & 12.7 & 118 \\
\hline SPT@0.1 m & 8 & 6 & 32 \\
\hline
\end{tabular}

The results show that at around $4 \mathrm{~mm}$ of settlement, the ultimate bearing capacity at the break point $\left(\mathrm{q}_{\mathrm{u}(\mathrm{b})}\right)$ on load settlement curve can be realized. The ultimate bearing capacity from the cement stabilized ground at 7 days curing is 6-7 times higher than that of the compacted Khon Kaen loess with similar compaction condition. From the result of natural ground [15], $\mathrm{q}_{\mathrm{u}(25)}$ is about $3.7 \mathrm{t} / \mathrm{m}^{2}$ (36 $\mathrm{kPa}$ ) for $0.3 \times 0.3 \mathrm{~m}$ plate. This means that the extra $\mathrm{q}_{\mathrm{u}(25)}$ is about 5 times only from the 95\% modified compaction on the ground. Also from the SPT, [13] modifies an approximate $50 \%$ increase in allowable bearing capacity $\left(\mathrm{q}_{\mathrm{a}}\right)$ as shown in Eq.(2). Similarly, from [16-17], the distribution equations for computing $\mathrm{q}_{\mathrm{a}}$ for $25 \mathrm{~mm}$ settlement can be found. However, in [9] an estimated $\mathrm{q}_{\mathrm{a}}$ of cohesionless soil from SPT values in Eq.(3) can be expressed as

$$
\begin{aligned}
& \qquad \mathrm{q}_{\mathrm{a}}(\mathrm{kPa})=\mathrm{N}_{55} \mathrm{~K}_{\mathrm{d}} / 0.05 ; \mathrm{B} \leq 1.2 \mathrm{~m} \\
& \text { where } \quad \mathrm{K}_{\mathrm{d}}=1+0.33\left(\mathrm{D}_{\mathrm{f}} / \mathrm{B}\right) \leq 1.33[18] \\
& \\
& \mathrm{B}=\text { width of foundation in } \mathrm{m} \\
& \mathrm{D}_{\mathrm{f}}=\text { depth of foundation in } \mathrm{m}
\end{aligned}
$$

$$
\mathrm{q}_{\mathrm{a}}(\mathrm{kPa})=30 \mathrm{~N}_{\mathrm{F}}
$$

where $\mathrm{N}_{\mathrm{F}}=$ average value of $\mathrm{N}_{55}$ from $\mathrm{D}_{\mathrm{f}}$ to $0.75 \mathrm{~B}$
All of the results to estimate the bearing capacity are illustrated in Table 11. They show that the bearing capacity obtained from the plate load test is higher than that from the unconfined compression test and that from the SPT estimation via Bowles and Parry equation from Eq.(2) and Eq.(3), respectively. One of the reason that $\mathrm{q}_{\mathrm{u}}(\mathrm{UCS})$ is less, is the 2 hours soaking condition before UC testing especially on only soil specimen. This causes the strength drop. In case of cement-soil blends permeability decreases and strength characteristics increases due to cementation products as well as reducing the effect on decreasing the strength drop from soaking. Finally, in the case of predicting values from SPT, Khon Kaen loess can be classified as clayey sand (SC) that may gain extra bearing capacity from cohesion. This is difference from both equations established by testing on cohesionless soil.

Table 11 Comparison in bearing capacity

\begin{tabular}{lcc}
\hline Type of material & Soil & $\begin{array}{c}\text { Soil-cement } \\
\text { @7 day }\end{array}$ \\
\hline UC Test & & \\
- $\mathrm{qu}_{\mathrm{u}}(\mathrm{UCS})$ & 4.99 & 146.70 \\
SPT & 8 & 32 \\
- $\mathrm{q}_{\mathrm{a}}$ (Bowles) & 10.3 & 55.1 \\
- $\mathrm{q}_{\mathrm{a}}$ (Parry) & 15.0 & 80.1 \\
Plate Load Test & & \\
- $\mathrm{qu}(25)$ & 23.4 & 162 \\
- $\mathrm{q}_{\mathrm{u}(\mathrm{b})}$ & 20.0 & 120 \\
\hline
\end{tabular}

\section{CONCLUSIONS}

The main problem when using Khon Kaen loess as the foundation of building or base of highway is bearing capacity loss and high collapsibility. In which Table 11 is a comparison in bearing capacity settlement due to an increasing in moisture content. For settlement problem, it can be eliminated only by highly compacting ground to change the moderate trouble to negligible collapsibility. However, in term of bearing capacity on Khon Kaen loess when soaking, only the compaction modification fails to meet the requirement even for base of highway. When the ground were compacted with $95 \%$ modified proctor at further OMC value, soil cement stabilization with above $6 \%$ amount of cement by weight are used to achieve the requirement. Also in the field test, the bearing capacity of the loess ground from compaction modification alone is not enough to meet the requirement. Therefore, cement should be added. For comparison of the result from laboratory and in situ test, the bearing capacity obtained from plate load test found a good relationship with the bearing capacity achieved from UC testing with less the effect of additional water. Laboratory test is rapidly emerging 
as a possible alternative to predict the bearing capacity and settlement.

\section{ACKNOWLEDGEMENTS}

The authors gratefully acknowledge financial support provided by Khon Kean University. Great gratitude is also given to Ms.Supawadee Srilachom and Ms.Issareeya Fuangsuwan for acquisition of data.

\section{REFERENCES}

[1] Udomchoke, V., 1991. Origin and Engineering Characteristics of the Problem Soil a in the Khorat Basin, Northeastern Thailand, Ph.D. dissertation, Asian Institute of Technology, Bangkok, Thailand.

[2] Yasufuku, N, Ochiai, H and Hormdee, D. (2006). An Empirical Relationship for Predicting Soil Collapsibility due to Soaking under Compression and Shear. ASCE:Geotechnical Special Publication. $4^{\text {th }}$ International Conference on Unsaturated Soils (UNSAT 2006). 1037-1048. 10.1061/40802(189)84.

[3] Hormdee, D., 2008.Investigation on Collapse Potential of Loess Soil, Proceedings of the Eighteenth (2008 International Offshore and Polar Engineering Conference 6-11 July 2008, Vancouver, Canada

[4] Evstatiev, D., 1988. Loess improvement methods, Eng. Geol. 25 (1988) 341-366.

[5] Adnan, B.A.,Erdil, T.R., 1992.Evaluation and control of collapsible soils, J. Geotechn. Eng., ASCE 118 (10) (1992) 1491-1504.

[6] Rezaei, M.,Ajalloeian, R.,Ghafoori, M., 2012. Geotechnical properties of problematic soils emphasis on collapsible cases inter, J. Geosci. 3 (February) (2012) 105-110.

[7] Cristopher, T.S., 2013. Expedient mitigation of collapsible loess in Northern Afghanistan, Int. J. Geo. Eng. Case Histories 2 (May 2013) 252-257.

[8] Samir, I.S., 2014. The assessment of the collapse potential of fills during inundation using plate load tests, Life Sci. J. 11 (8) (2014) 1001-1006.

[9] Holtz, W.G. and Gibbs H.J., 1951. Consolidation and Related Properties of Loessial Soils, ASTM
Symp., Consolidation Testing Soils, STP, 126 (1951) 9-33.

[10] Jennings, J.E. and Knight, K., 1975. A guide to construction on or with materials exhibiting additional settlement due to collapse of grain structure. Proceedings of the 6th Regional Conference for Africa on Soil Mechanics and Foundation Engineering, Durban, South Africa, 1(1975) 99-105.

[11]ASTM D5333-03., 2003. Standard Test Method for Measurement of Collapse Potential of Soils, ASTM International, West Conshohocken, PA.

[12] ASTM - American Society for Testing Material. 2000. Standard Practice for Bearing Capacity of Soil for Static Load and Spread Footings (ASTM D 1194-94). West Conshohocken. Pennsylvania

[13] Bowles, J.E., 1997. Foundation Analysis and Design, 5th Edition, Mc Graw-Hill Book Co. New York.

[14] Meyerhoy, G.G., 1951. The Ultimate Bearing Capacity of Foundations, Geotechnique, Vol.2, no.4 (1951) 301-331.

[15]Prommin, T and Nuntasarn, R., 2019. International Journal of GEOMATE, Vol.17, Issue 63 (2019) 87 - 94.

[16] Meyerhoy, G.G., 1956. Penetration Test and Bearing Capacity of Cohesionless Soils, JSMFD, ASCE, Vol.82, SM 1 (1956) 1-19.

[17] Meyerhoy, G.G., 1974. General Report: Outside Europe, $1^{\text {st }}$ ESOPT, Stockhoim, Vol.2.1(1974), pp.40-48.

[18] Meyerhoy, G.G., 1965. Shollow Foundations, JSMFD, ASCE, Vol.91, SM 2, March, pp.21.31.

[19]Parry, R.H.G., 1997. Estimating Bearing Capacity of Sand from SPT Values, JGED, ASCE, Vol. 103, GT 9, Sept 1997, pp.1014-1019.

[20] Ahmad, A.A., Qasim, A.J., and Ali, A.J., 2009. Evaluation of Bearing Capacity from Field and Laboratory Tests, Eng. \&Tech. Journal, Vol.27 (2009), No.3.

Copyright (C) Int. J. of GEOMATE. All rights reserved, including the making of copies unless permission is obtained from the copyright proprietors. 